Original Article

\title{
MULTIPLE TREATMENT OF EREMURUS HIMALAICUS EXTRACTS AMELIORATES CARBON TETRACHLORIDE INDUCED LIVER INJURY IN RATS
}

\author{
AHLAM MUSHTAQ ${ }^{1}$, MUBASHIR HUSSAIN MASOODI ${ }^{2}$, ADIL FAROOQ WALI ${ }^{2}$, BASHIR AHMAD GANAI ${ }^{3 *}$ \\ ${ }^{1}$ Department of Biochemistry, ${ }^{2}$ Department of Pharmaceutical Sciences, ${ }^{3}$ Centre of Research for Development (CORD), University of \\ Kashmir, Srinagar, Jammu and Kashmir, 190006, India \\ Email: bbcganai@gmail.com
}

Received: 13 Feb 2015 Revised and Accepted: 22 Jul 2016

\begin{abstract}
Objective: Eremurus himalaicus Baker, an edible herb of North Western Himalayas, has not been scientifically assessed for hepatoprotective potential. The ethyl acetate extract (EHE), methanolic extract (EHM) and aqueous extract (EHA) of Eremurus himalaicus were therefore evaluated for potential hepatoprotective activity in Wistar strain albino rats.

Methods: Carbon tetrachloride $(1.5 \mathrm{ml} / \mathrm{kg}$ ) was employed as hepatotoxin and was given on Day 1 of the experiment. The extracts at a dose of 300 $\mathrm{mg} / \mathrm{kg}$ bw (EHE, EHM and EHA) and the standard at a dose of $10 \mathrm{mg} / \mathrm{kg}$ bw (Liv 52) were given for following $7 \mathrm{~d}$ and the biochemical parameters (SGOT, SGPT, ALP, TP, bilirubin and UA) were estimated in order to assess the liver function. Moreover, the liver tissue samples were examined for histopathological changes.

Results: The results for serum biochemical analysis in rats showed a rise in SGOT, SGPT, ALP and bilirubin levels and a decrease in TP and UA levels upon giving hepatotoxin. The administration of the extracts and standard drug, for a period of 7 d, showed a significant decrease in SGOT, SGPT, ALP and bilirubin levels and an increase in TP and UA levels for EHM when compared to the toxic group. These results correlated well with the histopathological findings of liver for normal, toxic and extract treated groups. The EHM treatment decreased the extent of fat deposition and necrosis caused by $\mathrm{CCl}_{4}$. The results were almost similar to the standard drug Liv 52 .
\end{abstract}

Conclusion: Collectively; the results indicate that EHM exhibits significant hepatoprotective activity against $\mathrm{CCl}_{4}$ induced $_{\text {hepatotoxicity. }}$

Keywords: Biochemical, Hepatoprotective, Hepatotoxin, Histopathological, Liver

(C) 2016 The Authors. Published by Innovare Academic Sciences Pvt Ltd. This is an open access article under the CC BY license (http://creativecommons. org/licenses/by/4. 0/) DOI: http://dx.doi.org/10.22159/ijpps.2016.v8i9.11237

\section{INTRODUCTION}

The liver is a vital organ in our body which not only plays a role in various physiological functions but also protects our body against the ill effects of drugs and chemicals; endogenous as well as exogenous. Some of these drugs and chemicals act as hepatotoxic agents and induce various liver disorders [1]. Hepatic problems are accountable for a number of deaths worldwide. There has been a remarkable scientific advancement in the field of hepatology, however, the pharmacotherapeutic options available for hepatic disorders are very inadequate and hence the requirement for the development of new hepatoprotective drugs is the need of the hour [2].

Synthetic drugs available in the market come with severe undesirable side effects which lead to the growing demand to focus on ethnopharmacological approaches of drug discovery. Traditional medical practitioners have been using plant extracts for the treatment of liver disorders for centuries [3, 4]. Also, a number of plant extracts have been shown to protect against $\mathrm{CCl}_{4}$ induced hepatotoxicity. However, a lot of plants are still unexplored and need to be worked upon.

Eremurus himalaicus (Himalayan Desert Candle) is a plant that can be easily identified by its tall, stout, spike-like cluster of hundreds of white flowers with protruding orange anthers [5]. The edible herb, Eremurus himalaicus is found on rocky slopes of the drier areas of the Himalayas at altitudes of 2100-3300 m asl. The local names of this plant are Kaihloon, Hulla, Dharshaag, Bulkutor Yalun and Chhil haak. Its leaves and roots are consumed as food. The leaves are cooked as a vegetable [6-8]. When the leaves are young, these are consumed in the treatment of anemia [9]. Also, its leaves are widely used as a galactagogue by practitioners of traditional systems of medicines [10]. It is an almost unexplored plant as far as the screening of various biological activities is concerned. This study is aimed at adding to the biological activity profile of this plant besides providing a new hepatoprotective drug to the mankind. The amelioration of $\mathrm{CCl}_{4}$ induced hepatotoxicity by this plant has not been evaluated yet and this study is the first step in this direction.

\section{MATERIALS AND METHODS}

\section{Chemicals and solvents}

All the solvents, drugs and chemicals (used in the study were obtained commercially and were of analytical grade. The solvents (ethyl acetate, methanol) were acquired from MERCK; the chemicals $\left(\mathrm{CCl}_{4}\right.$, liquid paraffin) were acquired from MERCK and SigmaAldrich; the standard drug (Liv 52) manufactured by Himalaya Herbal Health Care was acquired from the local drug store, and the autoanalyser kits were acquired from Erba.

\section{Plant material collection and identification}

The first step was the collection of the plant from Faqir Goojree area of Dhara, Srinagar, Kashmir at the proper time (in the month of May). The collected plant material was properly identified and the specimen voucher was deposited in The Centre for Biodiversity and Taxonomy, Department of Botany, University of Kashmir under herbarium number: 1765 (KASH).

\section{Extraction}

The coarsely powdered plant material was extracted sequentially with different solvents of increasing polarity (petroleum ether, ethyl acetate, methanol and distilled water) by soxhlet extraction method. The recovered extracts were filtered and concentration of filtrate was done under reduced pressure at $35-45^{\circ}$ and finally the dried extracts were stored at $4{ }^{\circ} \mathrm{C}$ in well-labeled storage vials for further experimental use [11].

\section{Experimental animals}

Wistar rats of both sexes weighing 150-200 g were employed for the study. The animals were procured from The Central Animal House of Indian Institute of Integrative Medicine (IIIM) Jammu. The animals were fed with standard diet and water was provided ad libitium. The animals were maintained at standard conditions under the approval 
of the Institutional Animal Ethics Committee (IAEC) Department of Pharmaceutical Sciences, Faculty of Applied Sciences and Technology, University of Kashmir, Srinagar (Registration No. F(IAEC-Approval)KU/2015/14; dated: 21-08-2015).

\section{Acute toxicity testing and dose selection}

The acute toxicity testing was performed as per Organization for Economic Cooperation and Development (OECD) guidelines no 425. Healthy Wistar strain male albino rats were used for the study. As per the guidelines, the only limit test was performed since the plant is locally used as a vegetable. The dose selection was done on the basis of the result of acute toxicity test; a random value that was less than the $\mathrm{LD}_{50}$ value was selected so that no toxic effect would be exerted by the extracts.

\section{Administration of hepatotoxin}

Carbon tetrachloride mixed with liquid paraffin in a ratio of 1:1 was employed as hepatotoxin and was administered intraperitoneally (i. p) to each rat at a dose of $1.5 \mathrm{ml} / \mathrm{kg}$ body weight.

\section{Antihepatotoxic activity}

The antihepatotoxic activity was screened using the standard methodologies $[12,13]$. The experimental animals were divided into six groups, each group consisting of 5 rats. Group (I) which served as normal control received normal saline per orally (p. o). Group (II) which served as toxic control group received hepatotoxin on Day 1 to produce toxicity in the liver. Group (III) was given a single dose of hepatotoxin and then Liv $52(100 \mathrm{mg} / \mathrm{kg} \mathrm{b} . \mathrm{w}, \mathrm{p} . \mathrm{o})$ was given for $7 \mathrm{~d}$. Group (IV-VI) received a single dose of hepatotoxin on Day 1 and a daily dose of EHE, EHM and EHA (300 mg/kg b. w, p. o) for $7 \mathrm{~d}$ respectively.

On Day 8 the blood samples were withdrawn by orbital plexus puncturing and the rats were sacrificed by decapitation. The blood samples were allowed to clot for 30-40 min. at room temperature and serum was separated by centrifugation at $2500 \mathrm{rpm}$ for $15 \mathrm{~min}$. and various biochemical parameters were estimated. The liver tissue samples were sent for histopathological studies.

\section{Biochemical parameters}

The biochemical parameters that were estimated in order to assess the liver function included serum glutamic oxaloacetetic transaminase (SGOT) or AST, serum glutamic pyruvate transaminase (SGPT) or ALT, alkaline phosphatase (ALP), total proteins (TP), bilirubin and uric acid (UA) $[12,13]$. Their levels were analyzed on Sysmex autoanalyser.

\section{Histopathological studies}

The liver tissue samples were fixed in $10 \%$ formalin solution. This was followed by dehydration in graded alcohol and then the samples were embedded in paraffin. This was followed by sectioning on a microtome, followed by staining with a haematoxylin-eosin dye. Then the slides were taken for histopathological examination.

\section{Statistical analysis}

The data obtained for the serum biochemical parameters was represented as mean $\pm S$. E $(n=5)$. For determination of statistical significance, one-way analysis of variance (ANOVA) followed by Tukey's test was employed. $P$ values of less than 0.05 were considered significant.

\section{RESULTS}

The effect of Eremurus himalaicus on serum marker enzymes is presented in table 1 and table 2. The levels of serum SGOT, SGPT, ALP and bilirubin markedly elevated upon administration of $\mathrm{CCl}_{4}$ as indicated by levels of these enzymes in the toxic group. The levels of total protein and uric acid decreased in $\mathrm{CCl} 4$ treated animals. These changes were statistically significant when compared to the normal $(p<0.0001)$. The increase in the levels of these enzymes indicated liver damage.

Table 1: Effect of Eremurus himalaicus on SGOT, SGPT, ALP and bilirubin levels

\begin{tabular}{lllll}
\hline Group & SGOT (U/l) & SGPT (U/l) & ALP (U/l) & Bilirubin (mg/dL) \\
\hline Normal & $69.21 \pm 2.53$ & $57.51 \pm 5.93$ & $68.3 \pm 4.27$ & $0.98 \pm 0.05$ \\
Toxic control & $176.14 \pm 2.92^{\mathrm{a}}$ & $177.17 \pm 5.76^{\mathrm{a}}$ & $130.24 \pm 5.23 \mathrm{a}$ & $2.35 \pm 0.05^{\mathrm{a}}$ \\
Standard & $72.61 \pm 3.68^{\mathrm{b}}$ & $60.02 \pm 5.51^{\mathrm{b}}$ & $75.91 \pm 6.90^{\mathrm{b}}$ & $1.03 \pm 0.03^{\mathrm{b}}$ \\
EHM & $75.52 \pm 4.23^{\mathrm{b}}$ & $66.81 \pm 3.07^{\mathrm{b}}$ & $77.22 \pm 4.61^{\mathrm{b}}$ & $1.06 \pm 0.03^{\mathrm{b}}$ \\
EHE & $168.1 \pm 3.54^{\mathrm{a}, \mathrm{c}, \mathrm{e}}$ & $163.42 \pm 2.98^{\mathrm{a}, \mathrm{c}, \mathrm{e}}$ & $119.17 \pm 6.64^{\mathrm{a}, \mathrm{d}, \mathrm{e}}$ & $2.31 \pm 0.04^{\mathrm{a}, \mathrm{e}}$ \\
EHA & $170.61 \pm 4.11^{\mathrm{a}, \mathrm{e}}$ & $169.4 \pm 4.96^{\mathrm{a}, \mathrm{e}}$ & $125.78 \pm 5.72^{\mathrm{a}, \mathrm{e}}$ & $2.39 \pm 0.03^{\mathrm{a}, \mathrm{e}}$ \\
\hline
\end{tabular}

Values expressed as mean $\pm \mathrm{SD}, \mathrm{n}=6$, One way ANOVA followed by Tukey's multiple comparison post hoc test, aP $<0.0001$ when compared with normal group; ${ }^{\mathrm{P}}<0.0001$, $\mathrm{c} \mathrm{P}<0.01$, d $\mathrm{P}<0.05$ when compared with toxic group; e $\mathrm{P}<0.0001$ when compared with standard group, EHM stands for Eremurus himalaicus methanol extract; EHE stands for Eremurus himalaicus ethyl acetate extract; EHA stands for Eremurus himalaicus aqueous extract

Table 2: Effect of Eremurus himalaicus on total protein and uric acid levels

\begin{tabular}{lll}
\hline Group & Total protein $\mathbf{( m g / d L )}$ & Uric acid $(\mathbf{m g} / \mathbf{d L})$ \\
\hline Normal & $6.95 \pm 0.06$ & $2.8 \pm 0.05$ \\
Toxic & $6.37 \pm 0.09^{\mathrm{a}}$ & $1.39 \pm 0.05^{\mathrm{a}}$ \\
Standard & $6.89 \pm 0.08^{\mathrm{b}}$ & $2.78 \pm 0.04^{\mathrm{b}}$ \\
EHM & $6.84 \pm 0.08^{\mathrm{b}}$ & $2.74 \pm 0.04^{\mathrm{b}}$ \\
EHE & $6.27 \pm 0.07^{\mathrm{a}, \mathrm{c}}$ & $1.29 \pm 0.06^{\mathrm{a}, \mathrm{c}}$ \\
EHA & $6.3 \pm 0.06^{\mathrm{a}, \mathrm{c}}$ & $1.37 \pm 0.05^{\mathrm{a}, \mathrm{c}}$ \\
\hline
\end{tabular}

Values expressed as mean $\pm \mathrm{SD}, \mathrm{n}=6$, One way ANOVA followed by Tukey's multiple comparison post hoc test, a $\mathrm{P}<0.0001$ when compared with normal group; b $\mathrm{P}<0.0001$ when compared with toxic group; ${ }^{\mathrm{C}} \mathrm{P}<0.0001$ when compared with standard group, EHM stands for Eremurus himalaicus methanol extract; EHE stands for Eremurus himalaicus ethyl acetate extract; EHA stands for Eremurus himalaicus aqueous extract

The different extracts of Eremurus himalaicus (EHE, EHM and EHA), at a dose of $300 \mathrm{mg} / \mathrm{kg}$ bw respectively, were administered to the rats in order to find out their protective effect on liver damage caused by hepatotoxin $\mathrm{CCl}_{4}$. As is evident from the tables, EHM showed a highly significant decrease in the levels of serum SGOT $(\mathrm{p}<0.0001)$, SGPT $(\mathrm{p}<0.0001)$, ALP $(\mathrm{p}<0.0001)$ and bilirubin $(p<0.0001)$ and also a highly significant increase in total protein $(p<0.0001)$ and uric acid levels $(p<0.0001)$ when compared to toxic group. These values were non-significant when compared to the values obtained for normal group and standard group (Liv 52), which implies that EHM and Liv 52 exhibit almost similar hepatoprotective efficacies.

The effect of EHE on the values of serum marker enzymes SGOT $(\mathrm{p}<0.01)$, SGPT $(\mathrm{p}<0.01)$ and ALP $(\mathrm{p}<0.05)$ was also significant; however, the values were non-significant for bilirubin, total protein, 
and uric acid when compared to the toxic group. The values were significant for all the enzymes when compared to normal group and standard treated group, which implies that the effect of EHE on hepatoprotection is much less than that of the standard drug Liv 52.

The results for EHA revealed that it has no hepatoprotective potential as the values were significant for all the marker enzymes when compared to normal and standard treated groups. Also, the values were non-significant when compared to the toxic group.
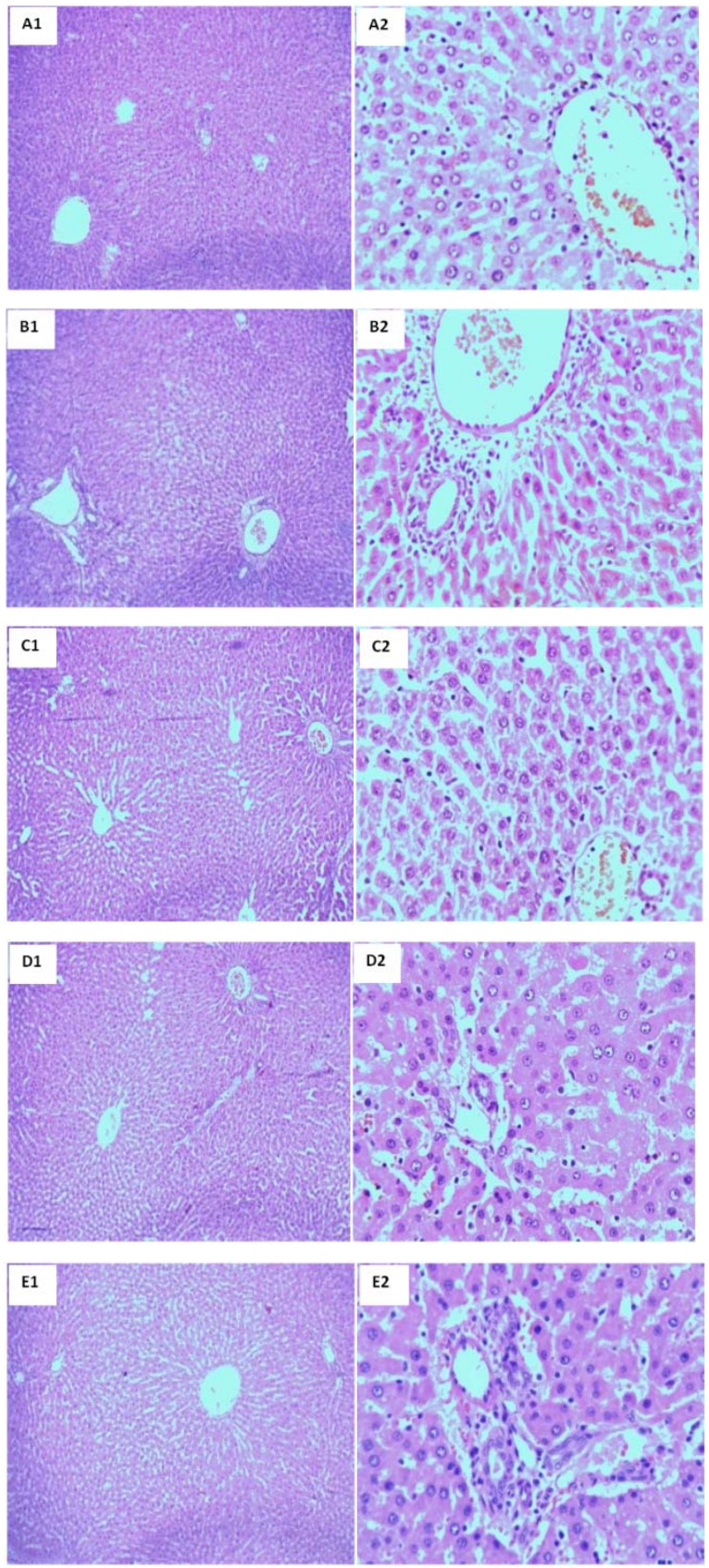

Fig. 1: Micrographs of rat liver sections of,

(A1) Normal group at low power; (A2) Normal group at high power; (B1) Toxic group at low power; (B2) Toxic group at high power; (C1) Ethyl acetate extract treated group at low power; (C2) Ethyl acetate extract treated group at high power; (D1) Methanol extract treated group at low power; (D2) Methanol extract treated group at high

power; (E1) Standard treated group at low power; and (E2) Standard treated group at high power

The histopathological studies were also in concurrence with the results obtained for biochemical parameters. There was evident hepatocellular damage in the toxic group in comparison to the normal group. The standard treated group showed prevention of the histopathological aberrations caused due to $\mathrm{CCl}_{4}$. Amongst the extract treated groups, the group treated with EHM showed utmost recovery of hepatocytes which indicates its hepatoprotective potential. The group treated with EHE also showed discernible recovery; however, it was much less in comparison to EHM. The photomicrographic representations of the liver tissues of the respective groups are shown in fig. 1.

\section{DISCUSSION}

Any damage to the liver, which is related to altered or impaired functioning of the liver and is caused due to drug exposure or exposure to other noninfectious agents is defined as hepatotoxicity $[11,1]$.

In order to study the mechanism of hepatotoxicity and/or drug discovery for prevention of hepatotoxicity, various chemical toxins are used as the mock-up substances for causing hepatocyte damage. These substances include carbon tetrachloride, acetaminophen, thioacetamide and galactosamine [12-15]. The mechanisms by which these substances produce liver damage are different; however, the damage caused by these hepatotoxins is evaluated through the same parameters.

The carbon tetrachloride induced hepatotoxicity has probably been most extensively studied from both biochemical and pathological perspectives which provides an idea about its mechanism of toxicity [16-18]. $\mathrm{CCl}_{4}$ exerts its effect through trichloromethyl radical which gets bound to the cellular macromolecules and causes damage to the endoplasmic reticulum membrane lipids and causes leakage of enzymes $[19,20]$. Elevated levels of serum enzymes indicate that there is a loss of functional integrity of the cell membrane and hence cellular leakage due to toxicity produced by $\mathrm{CCl}_{4}[21]$.

In the present work, $\mathrm{CCl}_{4}$ induced hepatocyte damage which was evident from the increase in the serum marker enzymes SGOT, SGPT, ALP and bilirubin and a decrease in total protein and uric acid levels. The administration of a methanolic extract of Eremurus himalaicus and the standard drug Liv 52 caused a significant $(\mathrm{P}<0.0001)$ restoration of serum levels of these enzymes. The ethyl acetate extract also showed some restoration of the enzyme levels. This reversal of increased levels of serum enzymes by Eremurus himalaicus extracts may be due to various reasons which lead to membrane stabilization and hence prevent the leakage of intracellular contents. Another reason may be that it prevents hepatocyte damage and induces hepatocyte regeneration. This can be assumed on the basis of histopathological reports in which it was clear that the $\mathrm{CCl}_{4}$ treated group showed degenerative changes, whereas, the standard and extract treated groups showed not as much of degenerative changes. This provided further insight into the hepatoprotective effect of Eremurus himalaicus. Moreover, this plant has been reported to contain flavonoids, which are known to possess hepatoprotective activity [22,23]. Also, various studies have revealed that the plant extracts having antioxidant activity may protect against $\mathrm{CCl}_{4}$ induced hepatotoxicity; this occurs via inhibition of lipid peroxidation and enhancement of activity of antioxidant enzymes [24, 25]. Therefore, this may be considered as another reason for the hepatoprotective activity of this plant. Further studies are in progress to characterize the bioactive principles from this plant.

\section{CONCLUSION}

It can be concluded from the present study that the methanolic extract, and to some extent the ethyl acetate extract, of Eremurus himalaicus show a protective effect on the $\mathrm{CCl}_{4}$ induced liver damage as revealed by the biochemical and histopathological studies. This effect was found to be quite comparable to the standard hepatoprotective drug Liv 52. Further work is in progress for the identification of bioactive moiety/moieties responsible for this effect.

\section{CONFLICT OF INTERESTS}

Declared none. 


\section{REFERENCES}

1. Grattagliano I, Bonfrate L, Catia VD, Wang HH, Wang DQH, Portincasa P. Biochemical mechanisms in drug-induced liver injury. World J Gastroenterol 2009;15:4865-76.

2. Guntupalli M, Chandana V, Pushpangadan P, Shirwaiker AI. Hepatoprotective effects of rubiadin, a major constituent of rubia cordifolia Linn. J Ethnopharmacol 2006;103:484-90.

3. Schuppan D, Jia J, Brikhaus B, Hahn EG. Herbal products for liver disease: A therapeutic challenge for the new millennium. Heatology 1999;30:1099-104.

4. Guguloth S, Vivekanandan L, Singaravel S, Sheik HS, Thangavel S. Hepatoprotective activity of vitex negundo linn bark against chemical-induced toxicity in experimental rats. Pharmanest 2011;2:5-6.

5. Nayar M, Sastry A. Botanical Survey of India, Kolkata. Red Data Book of Indian Plants; 1987.

6. NPMASD-National policy and macro level action strategy on biodiversity. The government of India ministry of environment and forests New Delhi, Published: December; 1999.

7. Sharma OP. Threatened plants of Jammu region, North-West Himalaya and strategies for their conservation. State Forest Res Institute, Jammu, Jammu Kashmir 2008;11:37.

8. Satish K, Irshad AH. Wild edibles of kishtwar high altitude national Park in Northwest Himalaya, Jammu and Kashmir (India). Ethnobot Leaflets 2009;13:195-202.

9. Shailja T. Medicinal plants used by tribal inhabitants of Sirmour district, Himachal pardesh. Int J Sci Res 2011;2:125-7.

10. Dhiraj SR, Anjna DK. Traditional health practices by 'kinners'-A tribe in alpine and sub-alpine himalayas of kinnaur (Himachal Pradesh), India, department of botany, Rajkiya Kanya Mahavidhalaya, Shimla (H. P.). Life Sci Leafl 2011;22:1048-55.

11. Navarro VJ, Senior JR. Drug-related hepatotoxicity. N Engl J Med 2006;354:731-9.

12. Domenicali M, Caraceni $P$, Giannone F, Baldassarre M, Lucchetti $\mathrm{G}$, Quarta C. A novel model of $\mathrm{CCl}_{4}$-induced cirrhosis with ascites in the mouse. J Hepatol 2009;51:991-9.

13. Kucera O, Cervinkova Z, Lotkova H, Krivakova P, Rousar T, Muzakova V. Protective effect of adenosylmethionine against galactosamine-induced injury of rat hepatocytes in primary culture. Physiol Res 2006;55:551-60.

14. Ledda-Columbano GM, Coni P, Curto M, Giacomini L, Faa G, Oliverio S. Induction of two different modes of cell death, apoptosis and necrosis, in rat liver after a single dose of thioacetamide. Am J Pathol 1991;139:1099-109.

15. Rousar $\mathrm{T}$, Kucera $\mathrm{O}$, Krivakova $\mathrm{P}$, Lotkova $\mathrm{H}$, Kandar $\mathrm{R}$, Muzakova $\mathrm{V}$, et al. Evaluation of oxidative status in acetaminophen-treated rat hepatocytes in culture. Physiol Res 2009;58:239-46.

16. Akram E, Pejman M, Maryam B, Jalal Z. Hepatoprotective activity of cinnamon ethanolic extract against $\mathrm{CCl}_{4}$-induced liver injury in rats. EXCLI J 2012;11:495-507.

17. Chatterjee TK. Medicinal plants with hepatoprotective properties. Herbal Options. Books and Applied Allied (P) Ltd., Calcutta; 2000. p. 143.

18. Rubinstein D. Epinephrine release and liver glycogen levels after carbon tetrachloride administration. Am J Physiol 1962;203:1033-7.

19. Johnson DE, Kroening C. Mechanism of early carbon tetra chloride toxicity in cultured rat hepatocytes. Pharmacol Toxicol 1998;83:231-9.

20. Kaplowitz N, Aw TY, Simon FR, Stolz A. Drug-induced hepatotoxicity. Ann Intern Med 1986;104:826-39.

21. Drotman R, Lawhan G. Serum enzymes are indications of chemical-induced liver damage. Drug Chem Toxicol 1978;1:163-71.

22. Seevola D, Baebacini GM, Bona S. Flavonoids and hepatic cyclic monophosphates in liver injury. Boll Ins Sieroter Milan 1984;63:777-82.

23. Wegner T, Fintelmann V. Flavonoids and bioactivity. Wien Med Wochenschr 1999;149:241-7.

24. Shahjahan M, Sabitha KE, Jainu M, Devi CSS. Effect of Solanum trilobatum against carbon tetrachloride induced hepatic damage in albino rats. Indian J Med Res 2004;120:194-8.

25. Sheweita SA, El-Gabar MA, Bastawy M. Carbon tetrachlorideinduced changes in the activity of phase II drug-metabolizing enzyme in the liver of male rats: role of antioxidants. Toxicology 2001;165:217-24.

\section{How to cite this article}

- Ahlam Mushtaq, Mubashir Hussain Masoodi, Adil Farooq Wali, Bashir Ahmad Ganai. Multiple treatments of Eremurus himalaicus extracts ameliorates carbon tetrachlorideinduced liver injury in rats. Int J Pharm Pharm Sci 2016; 8(9):24-27. 